ISSN 1420-3049

www.mdpi.com/journal/molecules

Review

\title{
The Nrf2 System as a Potential Target for the Development of Indirect Antioxidants
}

\author{
Kyeong-Ah Jung and Mi-Kyoung Kwak* \\ College of Pharmacy, Yeungnam University, Gyeongsan, Gyeongsangbuk-do 712-749, Korea \\ * Author to whom correspondence should be addressed; E-Mail: mkwak@ynu.ac.kr; Tel.: +82-53- \\ 810-2823; Fax: +82-53-810-4654.
}

Received: 19 September 2010; in revised form: 18 October 2010/ Accepted: 20 October 2010 / Published: 20 October 2010

\begin{abstract}
Oxidative stress causes damage to multiple cellular components such as DNA, proteins, and lipids, and is implicated in various human diseases including cancer, neurodegeneration, inflammatory diseases, and aging. In response to oxidative attack, cells have developed an antioxidant defense system to maintain cellular redox homeostasis and to protect cells from damage. The thiol-containing small molecules (e.g. glutathione), reactive oxygen species-inactivating enzymes (e.g. glutathione peroxidase), and phase 2 detoxifying enzymes (e.g. $\mathrm{NAD}(\mathrm{P}) \mathrm{H}$ : quinine oxidoreductase 1 and glutathione-Stransferases) are members of this antioxidant system. NF-E2-related factor 2 (Nrf2) is a CNC-bZIP transcription factor which regulates the basal and inducible expression of a wide array of antioxidant genes. Following dissociation from the cytosolic protein Keap1, a scaffolding protein which binds $\mathrm{Nrf} 2$ and $\mathrm{Cul3}$ ubiquitin ligase for proteasome degradation, Nrf2 rapidly accumulates in the nucleus and transactivates the antioxidant response element in the promoter region of many antioxidant genes. The critical role of Nrf2 has been demonstrated by various animal studies showing that mice with a targeted disruption of the $n r f 2$ gene are prone to develop lesions in response to environmental toxicants/carcinogens, drugs, and inflammatory insults. In this review, we discuss the role of the Nrf2 system, with particular focus on Nrf2-controlled target genes and the potential pleiotropic effects of Nrf2 activation of indirect antioxidants.
\end{abstract}

Keywords: indirect antioxidants; oxidative stress; Nrf2; Keap1 


\section{Introduction: Reactive Oxygen Species and Oxidative Stress}

Reactive oxygen species (ROS) are constantly produced in aerobic organisms as by-products of normal oxygen metabolism and include free radicals such as superoxide anion $\left(\mathrm{O}_{2}{ }^{-}\right)$and hydroxyl radical $\left(\mathrm{OH}^{-}\right)$, and non-radical hydrogen peroxide $\left(\mathrm{H}_{2} \mathrm{O}_{2}\right)$. Superoxide anion is a common precursor of ROS and is involved in two pathways: i) rapid conversion into hydrogen peroxide and oxygen by superoxide dismutase (SOD) and ii) generation of highly toxic peroxynitrite via reaction with nitric oxide [1,2]. Further, hydrogen peroxide can be converted into hydroxyl radicals, particularly in the presence of transition metals such as iron and cobalt [3]. The mitochondrial respiratory chain and enzymatic reactions by $\mathrm{NAD}(\mathrm{P}) \mathrm{H}$ oxidase, xanthine oxidase, cyclooxygenases, and lipoxygenase, are endogenous sources of ROS [4]. Exogenous ROS-inducing stressors include ionizing radiation, UV light, and divergent oxidizing chemicals.

At low concentrations, ROS serve as an important second messenger in cell signaling; however, at higher concentrations and long-term exposure, ROS can damage cellular macromolecules such as DNA, proteins, and lipids, which leads to necrotic and apoptotic cell death [4]. To restrict the potential toxicity of ROS, cells developed the antioxidant system. A nonenzymatic system involving thiolcontaining small molecules such as glutathione (GSH) and thioredoxin (Txn) neutralizes ROS via direct interactions. An enzymatic system, including catalase, glutathione peroxidase (GPx), and peroxiredoxins (Prdx) reduce hydrogen peroxide to water. However, excess ROS can overwhelm the capacity of the antioxidant system, which leads to perturbation of cellular redox balance. Oxidative stress is a condition of imbalance between ROS formation and cellular antioxidant capacity due to enhanced ROS generation and/or dysfunction of the antioxidant system. Protein carbonyls, 8hydroxyguanosine adducts, and lipid peroxides including 4-hydroxy-2-nonenal and isoprostane are biochemical markers of oxidative stress representing ROS-mediated damage to proteins, nucleic acids, and lipids [5]. Biochemical alterations in these macromolecular components can lead to various pathological conditions and human diseases: cancer, neurodegeneration, atherosclerosis, inflammation, and aging. In particular, ROS can stimulate cell proliferation, invasion, migration, and angiogenesis, and can evade apoptosis in cancer cells [6].

Recent discoveries in the cell biology of the cellular antioxidant system gave rise to the novel concept of "indirect antioxidants". Indirect antioxidants act through the augmentation of cellular antioxidant capacity by enhancing gene expression. This review describes the role of the transcription factor Nrf2 in antioxidant gene regulation and its implications in various pathology and disease models. We suggest that small molecule Nrf2 activators may be a promising class of indirect antioxidants for the prevention/treatment of a wide array of human diseases.

\section{Cellular Antioxidant System}

\subsection{Directly Acting Antioxidant Proteins}

Several proteins are directly involved in ROS removal. These include SOD, catalase, GPx, and small thiol molecules GSH and Txn. Among these, catalase, SOD, and GPx directly neutralize ROS. Mammalian catalase, with a molecular weight of $240 \mathrm{kDa}$ is a tetramer of four identical subunits containing a porphyrin heme group [7] and is expressed in all tissues, but at particularly high 
concentrations in the liver, erythrocytes, and kidneys [8]. Catalase catalyzes the conversion of two molecules of hydrogen peroxide into two molecules of water and one molecule of oxygen in a decomposition reaction that can prevent the formation of highly reactive hydroxyl radicals from hydrogen peroxide. Human GPx is a selenoprotein which takes the form of 5 isotypes (GPx 1, 2, 3, 4, and 6), and can reduce hydrogen peroxide and soluble fatty acid hydroperoxides using two molecules of GSH as a co-substrate [9]. The antioxidative role of GPx has been demonstrated by gene knock-out studies in animal models: GPX1 deficiency in mice led to abnormalities in endothelial and cardiomyocyte function due to severe oxidative stress [10].

GSH and Txn serve as substrates for GPx and Prdx. GSH is highly abundant (at millimolar concentrations) cellular tripeptide L- $\gamma$-glutamyl-L-cysteinyl-glycine and its biosynthesis occurs in the cytoplasm of most tissues via the action of $\gamma$-glutamate cysteine ligase (GCL) and GSH synthetase [11, 12]. GCL is a heterodimer comprised of a catalytic subunit (GCLC) and a modulatory subunit (GCLM) [13]. Because of its high reactivity with free radicals, GSH is easily oxidized: biosynthesis and enzymatic reduction of disulfide by GSH reductase can rapidly supply GSH. Therefore, the ratio of GSH to oxidized GSH (GSSG) has been used as a marker of cellular redox status. Txn is located in the inner mitochondrial membrane and is involved in the reduction of hydrogen peroxide, lipid peroxide, and proteins with oxidatively modified sulfhydryl residues [14]. Txn reductase catalyzes the reduction of oxidized Txn using $\mathrm{NAD}(\mathrm{P}) \mathrm{H}$, thereby maintaining a stable ratio of reduced to oxidized Txn.

\subsection{Phase 2 Detoxifying Enzymes as Antioxidant Proteins}

Phase 2 detoxifying enzymes were originally recognized as xenobiotic metabolizing enzymes. Xenobiotics, which include various environmental chemicals, carcinogens, and drugs, undergo sequential two-step metabolism. Phase 1 enzymes primarily catalyze the introduction of functional groups into hydrophobic organic molecules through the action of cytochrome P450 enzymes [15]. Phase 2 enzymes are largely responsible for the elimination of xenobiotics by forming conjugated metabolites using hydrophilic molecules such as GSH and glucuronic acid. Phase 2 enzymes can be classified into four different categories: i) classical conjugating enzymes: glutathione $S$-transferases (GSTs) and UDP-glucuronosyl transferases (UGTs); ii) enzymes contributing to biosynthesis/recycling of thiols: GCL, GSH reductase, and Txn reductase; iii) enzymes involved in the reduction of reactive intermediates: $\mathrm{NAD}(\mathrm{P}) \mathrm{H}$ : quinine oxidoreductases (NQOs) and epoxide hydrolase (EH); iv) stressresponse proteins: heme oxygenase-1 (HO-1) and ferritin [16, 17]. Due to their role in maintaining redox balance, thiol homeostasis, and excretion of reactive metabolites (e.g., peroxides, epoxides, aldehydes, quinones), phase 2 detoxifying enzymes are now often classified as antioxidant proteins [16]. Further, because electrophiles can evoke GSH depletion and macromolecular damage, many environmental chemicals are regarded as oxidative stressors. One such example is a tobacco-related chemical benzo $[a]$ pyrene $(\mathrm{B}[a] \mathrm{P})$ : its reactive metabolic intermediate $\mathrm{B}[a] \mathrm{P}-7,8$ dihydrodiol-9,10 epoxide is a potent carcinogenic electrophile that depletes GSH and causes DNA damage [18].

GSTs are ubiquitous, multifunctional enzymes that detoxify endogenous and exogenous electrophiles, including epoxides, aldehydes, and peroxides. There are seven distinct classes of GSTs based on amino-acid sequence similarities, physical structure of the genes, and immunological crossreactivity: alpha $(\alpha)$, mu $(\mu)$, omega $(\omega)$, pi $(\pi)$, sigma $(\sigma)$, theta $(\theta)$, and zeta $(\zeta)[19]$. Animal knockout 
studies have revealed the functional role of GSTs in the susceptibility to environmental electrophiles. In Gstp1/p2 null mice, the number of skin papillomas was significantly increased after exposure to the carcinogen 7,12-dimethylbenz(a)anthracene (DMBA) and 12-O-tetradodecanoyl-13-acetate (TPA) [20]. Lung cancer incidence after exposure to $\mathrm{B}[a] \mathrm{P}$ was increased in Gstp1-/- mice [21]. In humans, cytosolic GSTs display polymorphisms which likely contribute to inter-individual differences in the response to xenobiotics and susceptibility to cancer [19]. The Gstm1 null genotype is associated with an almost 2-fold higher risk for nasopharyngeal carcinoma in humans or animals [22].

UGTs catalyze the glucuronic acid conjugation reaction that mediates the major excretory pathway for pollutants and drugs, as well as endogenous compounds such as bilirubin, steroids, and hormones [23]. A number of studies have confirmed the protective role of UGTs against environmental chemicals and carcinogens: i) susceptibility to $\mathrm{B}[a] \mathrm{P}$ carcinogenesis was enhanced in ugt-deficient cultured rat skin fibroblast [24]; ii) elevated UGT1A1 in breast cancer cells reduced DMBA-DNA adduct formation [25].

NQO1 (previous names include DT-diaphorase or quinone reductase type 1), a key enzyme belonging to the family of homodimeric flavoproteins, facilitates quinone excretion by catalyzing the reduction of quinones to hydroquinones through a single-step two-electron reduction reaction [26]. Since the alternative one-electron reduction of quinone can form semihydroquinone, which is capable of generating ROS through redox-cycling, NQO1 functions to prevent oxidative DNA damage by environmental stressors. Further, NQO1 plays an important role in preserving endogenous antioxidants by maintaining ubiquinone and $\alpha$-tocopherol quinone in their reduced forms [27-29]. Therefore, mice with targeted disruption of nqo1 were highly susceptible to $\mathrm{B}[a] \mathrm{P}$-induced mouse skin carcinogenesis [30]. NQO1*2, the C609T substituted polymorphic form of NQO1, has low NQO1 enzymatic activity compared with wild-type [31] and has been associated with greater risk of cancer incidence including pediatric leukemia [32], colorectal cancer [33], and gastric cardiac carcinoma [34].

HO-1 catalyzes the catabolic metabolism of heme to produce carbon monoxide and bilirubin $[35,36]$. Due to its role in removing the potent pro-oxidant heme and generating endogenous antioxidants carbon monoxide and bilirubin, HO-1 exhibits strong antioxidant capacity [36]. Ferritin, an iron storage protein, exhibits its antioxidative function by sequestering free iron that is potentially toxic when reacted with hydrogen peroxide [37,38].

\section{Regulation of Antioxidant Genes by Nrf2}

\subsection{Antioxidant Response Element (ARE)}

It has long been known that many phase 2 genes, including GSTs and NQO, are regulated through a cis-acting element, the antioxidant response element (ARE), located in their promoters. ARE was first identified in the 5'-flanking region of the rat Gsta2 subunit gene (TAATGGTGACAAAGCA) [39] and this enhancer is essential for the inducible expression of Gsta2 in response not only to phenolic antioxidants and metabolizable planar aromatic compounds, but also hydrogen peroxide and ROS [40]. Similarly, ARE (TCACAGTGACTTGGCA) of the rat nqo1 gene is necessary for the inducible expression of this gene [41,42]; subsequently it was found that the rat nqo1 ARE was highly conserved in the human nqo1 gene (TCACAGTGACTCAGCA) [43]. In addition, GCLC and GCLM, which are genes encoding GSH biosynthetic enzyme subunits, contain multiple functional AREs; the human 
GCLM promoter retains tandem AREs, which are in opposite orientations [44,45]. In the promoter of the human GCLC gene, a reverse ARE (TCCCCGTGACTCAGCG) located at -3118 bp was identified as a functional ARE, responsible for induction in response to $\beta$-naphthoflavone and putative chemopreventive agents [46]. In an early study by Wasserman and Fahl et al. [47], the core sequence of ARE was proposed to be $5^{\prime}-{ }^{\mathrm{A}} / \mathrm{G}$ TGA $/{ }_{\mathrm{G}} \mathrm{NNNGCa} / \mathrm{c}-3{ }^{\prime}$. However, as more AREs are identified in a wide array of phase 2 genes, great variability in the core sequence of ARE was found, indicating that consensus ARE sequences may be dependent on the specific interrogated gene.

\subsection{Nrf2 Signaling for the Regulation of ARE-Driven Genes}

Based on the critical role of the ARE in antioxidant gene expression, the identification of transcription factors interacting with the ARE have long been a topic of interest. Extensive studies during the past decade have proven the notion that the transcription factor NF-E2-related factor 2 (Nrf2) is an essential element for regulation of the ARE [48-51]. Since the first demonstration that induction of nqo1 and gst gene expression was abrogated in t-butylhydroxyanisole (BHA)-treated $n r f 2 /$ - mouse [48], numerous studies have confirmed the crucial role of Nrf2 in the regulation of AREbearing genes in response to oxidants and electrophiles. Hepatic and gastric activities of GSTs and Nqo1 were reduced in $n r f 2$-deficient mice compared with wild-type mice, and the induction of these enzymes by a chemopreventive agent, oltipraz, was almost blunt in $n r f 2-/-$ mouse [52]. When the dominant mutant Nrf2 was overexpressed, hemin-inducible expression of HO-1 was largely inhibited [53].

Many chemicals can induce the translocation of Nrf2 from the cytoplasm to the nucleus, where it can transactivate AREs with other bZIP transcription factor partners, including small Maf proteins (Maf F, Maf G, and Maf K) and ATF4 [51,54-57]. As Nrf2 activators, several phytochemicals, typical cancer preventive agents, GSH-depleting agents, electrophiles, and heavy metals are known to induce the expression of ARE-driven genes. In an attempt to elucidate common gene clusters regulated by Nrf2, several comparative analyses of global gene expression have been performed in $n r f 2-/-$ mice following treatment with enzyme-inducing chemicals. In the initial demonstration by Kwak et al., the expression of 300 genes was increased by $3 H$-1,2,-dithiole-3-thione (D3T) treatment in wild-type mouse liver, whereas $77 \%$ of these inducible genes were not altered in $n r f 2-/-$ mice [58]. These Nrf2-dependent genes include clusters of phase 2 metabolizing enzymes such as GSTs and Nqo1, antioxidants, several cytochrome P450 enzymes, general enzymes, stress-response proteins, and the molecular chaperoneproteasome. Many of these Nrf2-dependent gene clusters were confirmed in other comparative gene analyses following treatment with isothiocyanates such as sulforaphane, phenolic antioxidants BHA and $t$-butyl hydroxyquinone ( $t \mathrm{BHQ}$ ), and synthetic oleanane triterpenoids [59-66], and representative antioxidant genes under the control of $\mathrm{Nrf} 2$ are summarized in Table 1. These comprehensive experimental approaches together with animal studies showing the loss of cytoprotective effect of enzyme inducers in $n r f 2-/-$ mice support the concept that Nrf2-target genes are primarily responsible for the advantageous action of phase 2 enzyme inducers. 
Table 1. Antioxidant genes regulated by Nrf2.

\begin{tabular}{|c|c|c|c|}
\hline Function & Gene & Species (organs) & Reference \\
\hline \multirow[t]{8}{*}{ GSH biosynthesis } & GCLC & Mouse (liver, lung) & {$[58,67]$} \\
\hline & & Human (HaCaT; keratinocyte) & {$[68]$} \\
\hline & GCLM & Mouse (liver, lung) & {$[58,67]$} \\
\hline & & Human (IMR- & {$[68,69]$} \\
\hline & & 32;neuroblastoma cell) & \\
\hline & & $(\mathrm{HaCaT})$ & \\
\hline & GSR & Mouse (liver, lung) & {$[70,71]$} \\
\hline & & Human (IMR-32, HaCaT) & {$[68,69]$} \\
\hline Glutathione & GPx1 & Mouse (cardiovascular, lung) & {$[72]$} \\
\hline \multirow[t]{3}{*}{ peroxidases } & GPx2 & Mouse (liver, lung) Rat (liver) & {$[73,74]$} \\
\hline & & Human (Caco-2;colon Cell) & {$[75]$} \\
\hline & & Rat (liver) & [76] \\
\hline \multirow{2}{*}{$\begin{array}{l}\text { Thioredoxin } \\
\text { reductase }\end{array}$} & TXNRD & Mouse (liver, lung) & {$[65,67]$} \\
\hline & & Human (IMR-32) & [69] \\
\hline Thioredoxin & TXN & Mouse (liver) & [58] \\
\hline \multirow{2}{*}{ Peroxiredoxin } & PRDX1 & Mouse (liver,lung) & {$[67,74]$} \\
\hline & PRDX6 & $\begin{array}{l}\text { Human (A549; lung derived } \\
\text { cell line) }\end{array}$ & {$[77]$} \\
\hline Superoxide & SOD1 & Mouse (liver) & [71] \\
\hline \multirow{3}{*}{ dismutase } & SOD2 & Mouse (liver) & [71] \\
\hline & SOD3 & Mouse (lung) & {$[67]$} \\
\hline & Catalase & Mouse (liver, lung) & {$[71,73]$} \\
\hline \multirow[t]{13}{*}{$\begin{array}{l}\text { Glutathione S- } \\
\text { transferases }\end{array}$} & GSTA1 & $\begin{array}{c}\text { Mouse (liver, lung, small } \\
\text { intestine) }\end{array}$ & {$[64,67,71]$} \\
\hline & GSTA2 & $\begin{array}{c}\text { Mouse (liver, lung, small } \\
\text { intestine) }\end{array}$ & {$[58,64,67]$} \\
\hline & GSTA3 & $\begin{array}{c}\text { Mouse (liver, lung, small } \\
\text { intestine) }\end{array}$ & {$[64,67,71]$} \\
\hline & GSTA4 & Mouse (liver) & {$[65]$} \\
\hline & GSTM1 & Mouse (liver, small intestine) & {$[58,64,65]$} \\
\hline & GSTM2 & Mouse (liver, small intestine) & {$[58,64,65]$} \\
\hline & GSTM3 & Mouse (liver, small intestine) & {$[58,64,65]$} \\
\hline & & Human (IMR-32) & [69] \\
\hline & GSTM4 & Mouse (liver) & {$[65]$} \\
\hline & GSTM5 & Mouse (liver) & [59] \\
\hline & GSTM6 & Mouse (liver) & {$[65]$} \\
\hline & MGST2 & Mouse (small intestine) & [64] \\
\hline & MGST3 & Mouse (liver, small intestine) & {$[58,64]$} \\
\hline \multirow{3}{*}{$\begin{array}{l}\text { UDP-glucuronosyl } \\
\text { transferase }\end{array}$} & UGT1A6 & Mouse (liver) & {$[74]$} \\
\hline & UGT2B1 & Mouse (liver) & [71] \\
\hline & UGT2B5 & Mouse (liver, small intestine) & {$[58,64]$} \\
\hline \multirow[t]{4}{*}{ Reduction } & NQO1 & $\begin{array}{c}\text { Mouse (liver, lung, small } \\
\text { intestine) }\end{array}$ & $\begin{array}{c}{[58,64,67]} \\
{[69]}\end{array}$ \\
\hline & AKR1A & Human (IMR-32) & {$[58,64]$} \\
\hline & AKR1B8 & Mouse (liver, small intestine) & {$[64,67]$} \\
\hline & & Mouse (liver, small intestine) & \\
\hline
\end{tabular}


Table 1. Cont.

\begin{tabular}{cccc}
\hline Heme oxygenase-1 & HO-1 & Mouse (liver) Rat (liver) & {$[59,76]$} \\
& & Human (IMR-32, HaCaT) & {$[68,69]$} \\
Hydrolysis & EPHX & Mouse (liver, small intestine) & {$[58,64]$} \\
Iron transport & Ferritin H & Mouse (ling) & {$[73]$} \\
& Ferritin L & Human (HaCaT) & {$[68]$} \\
& & Mouse (liver) & {$[65]$} \\
Detoxication & MT I & Human (HaCaT) & {$[68]$} \\
of heavy metals & MT II & Human (Hepryonic fibroblasts) & {$[56]$} \\
& & Mouse (embryonic fibroblasts) & {$[78]$} \\
Transport & MRP2 & Human (HepG2 Cell) & {$[56]$} \\
& MRP3 & Mouse (liver) & {$[78]$} \\
& & Mouse (liver) & {$[71]$} \\
26S Proteasome & Psma1,4,5,6,7 & Human (NSCLC, HBE1) & {$[71]$} \\
& Psmb1,2,3,4,5,6 & Mouse (liver) & {$[79]$} \\
& Psmc1,3 & Mouse (liver) & {$[58]$} \\
& Psmd1,5,7,11,12,13 & Mouse (liver) & {$[58]$} \\
& & Mouse (liver) & {$[58]$} \\
\end{tabular}

\subsection{Keap1 as a Protein Inhibitor of Nrf2}

Nrf2 has six highly conserved homologous regions named Neh1 to Neh6 [80]. The Neh1 domain has a bZIP region interacting with partner proteins for heterodimerization [81]. The Neh3 domain interacts with chromodomain helicase DNA-binding protein 6 (CHD6) [82], and two acidic transactivation domains, Neh4 and Neh5, cooperatively bind with CBP (cAMP response elementbinding protein-binding protein) [81]. The Neh2 domain located in the N-terminus of Nrf2 is known to be a regulatory domain responding to oxidative stress: Neh2 interacts with cytosolic protein, Kelchlike ECH-associated protein 1 (Keap1) and negatively controls Nrf2 function [83]. Keap1, which was originally isolated as an Nrf2-binding protein, is an actin-binding protein and has been thought to inhibit the function of Nrf2 by simply sequestering the protein in the cytoplasm $[83,84]$. However, as described in Figure 1, recent advances in Nrf2-Keap biology revealed that Keap1 functions as an adaptor protein between Nrf2 and Cul3, a component of the E3 ligase complex, and this binding promotes the continuous degradation of $\mathrm{Nrf} 2$ by the proteasome under normal conditions [85-87].

Since the dissociation of Nrf2 from Keap1 is the primary mechanism for Nrf2 activation, it will be an intriguing problem to determine how these two molecules interact with each other in different cellular environments. Recently, Yamamoto and colleagues have proposed the "hinge and latch" model to explain the response of Nrf2-Keap1 complex to stimuli [88,89]. Nrf2 contains 2 Keap1 binding sites within the Neh2 domain: DLG motif and ETGE motif, which enable the formation of a complex of one molecule of Nrf2 and two molecules of Keap1 [90,91]. Of note, these two sites have different binding affinities: the affinity of DLG motif to Keap1 is much weaker than that of ETGE. This led to the hypothetical "latch" binding of DLG-Keap1, which can be easily disturbed by Keap1 conformational changes of [88-91]. Since DLG binding involves the subsequent Cul3-proteasomal degradation of Nrf2, alterations in the DLG-Keap1 binding can result in the rescue of Nrf2 from degradation and 
accumulation of this protein within the nucleus. In recognition that Keap1 is a cysteine-rich protein (human and murine Keap1 contain 27 and 25 cysteines, respectively), modifications in sulfhydryl residues of Keap1 protein were initially speculated to result in protein conformational changes [83]. In fact, oxidative stress conditions and many exogenous chemicals alter the reducing status of cysteine residues of Keap1 and lead to Nrf2 translocation. As reactive cysteine residues mediating Nrf2 activation, an initial study by Dinkova-Kostova et al [92], has identified Cys257, Cys273, Cys288, and Cys297 to be dexamethasone-modified cysteine residues using mass spectrometry analysis. Subsequent independent studies confirmed that Cys273 and Cys288 are essential for Nrf2 activation in response to phase 2 enzyme inducers such as dithiolethiones and sulforaphane [91]. In addition to these, Cys151 was demonstrated to be required for the effect of sulforaphane and $t$ BHQ [93-95]. Taken together, these results indicate that Keap1 is a sensor protein responding to oxidative and environmental stresses through dynamic changes in cysteine reducing status (Figure 1).

Figure 1. Nrf2 and its regulation by Keap1. (A) Under normal conditions, Nrf2 is degraded by Keap1-Cul3-dependent pathway; (B) In the presence of indirect antioxidants, Keap1Nrf2 binding is disturbed and Nrf2 transactivates ARE-driven genes in the nucleus; (C) Protein structure of Keap1 and reactive cysteine residues for the action of Nrf2.

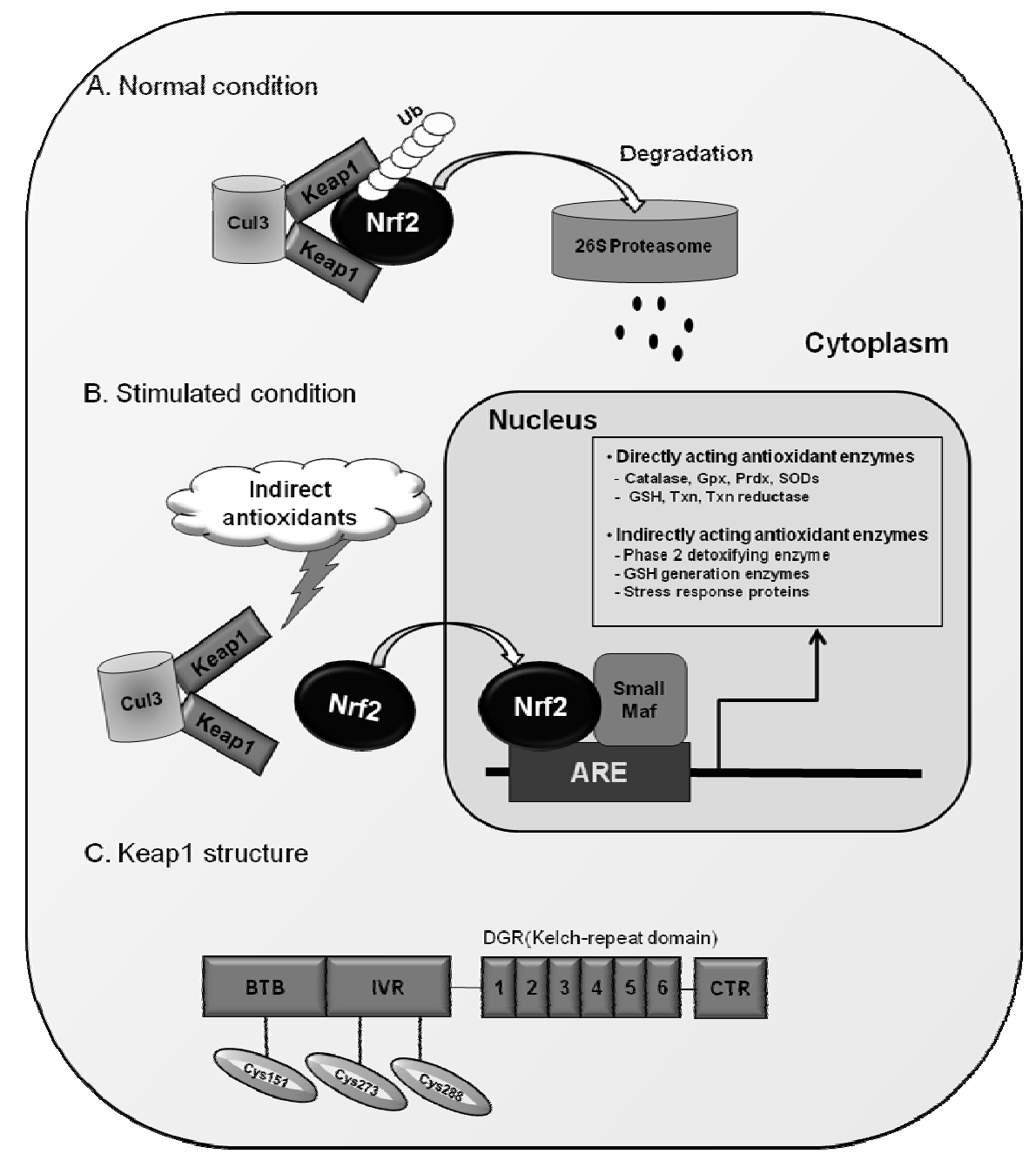




\section{Functional Role of the Nrf2 System: From Comparative Animal Studies}

Since the first finding of $\mathrm{Nrf2}$ as a master regulator of indirect antioxidant genes, various comparative animal studies using $n r f 2-/-$ mice have been performed to investigate the role of Nrf2 in the mammalian defense system. It is now widely accepted that cells and animals with a nrf2 null genotype are much more sensitive to environmental or oxidative stress conditions, leading to accelerated macromolecular damage, mutations, and apoptosis. The initial study by Chan et al. [96], demonstrated that $n r f 2-/-$ mice are highly susceptible to butylated hydroxytoluene (BHT)-induced lung damage and lethality in comparison to wild-type mice. A following independent study showed that Nrf2 is a critical factor for determining susceptibility to hyperoxic concentration of oxygen-induced lung injury in mouse [97,98]. As a proof of its role in the CNS, astrocytes from $n r f 2-/-$ mice showed higher rates of cell death in response to hydrogen peroxide treatment [62]. Murine embryonic fibroblasts (MEFs) isolated from $n r f 2-/-$ mice showed higher levels of cell death in response to treatment with the redox-cycling ROS generator menadione and GSH-depleting anticancer agent cisplatin [99, 100]. Incubation with diquat dibromide, another redox cycling bipyridylium herbicide, MEFs displayed markedly decreased cell viability, increased lipid peroxidation and GSH oxidation in comparison to wild-type cells [101].

Many electrophiles can cause oxidative stress leading to DNA mutations and carcinogenesis. As Nrf2 is a prime regulator for the expression of electrophile-detoxifying enzymes, the Nrf2 system has been recognized as a susceptibility determinant in response to chemical carcinogens. The first demonstration by Ramos-Gomez et al. showed that the incidence of gastric tumors was significantly increased in $n r f 2-/-$ mice following $\mathrm{B}[a] \mathrm{P}$ treatment and $\mathrm{B}[a] \mathrm{P}-\mathrm{DNA}$ adduct levels were concomitantly increased in these mutant mice [52,102]. Aoki et al. demonstrated that exposure of $n r f 2-/-$ mice to diesel exhaust particles, which are postulated as a probable causal factor in lung cancer, resulted in higher levels of oxidative DNA damage with concomitant increases in lung injury [103]. The incidence of urinary bladder carcinoma by BBN was significantly higher in $n r f 2-/-$ mice than in wild-type mice [104]. When treated with arsenic, $n r f 2-/-$ mice showed more severe pathological changes in the liver and bladder, and arsenicinduced DNA hypomethylation was significantly elevated in the absence of $n r f 2$ [105].

Recent reports support the role of $\mathrm{Nrf} 2$ in the inhibition of inflammatory injuries. Following treatment with lipopolysaccharide (LPS), peritoneal neutrophils from $n r f 2-/-$ mice exhibited increased NADPH oxidase-dependent ROS generation and levels of TNF-alpha, IL-6 and chemokines (Mip2 and Mcp-1) compared to wild-type neutrophils [106]. Nrf2-/- macrophages were more susceptible to damage induced by reactive oxygen/nitrogen species, as well as acrolein and cadmium, macrophage toxins [107]. In addition to its role in inflammation, Nrf2 plays an inhibitory role in the fibrogenic process: bleomycin-induced pulmonary fibrosis and cyclosporine-mediated renal fibrosis were aggravated in $n r f 2-/-$ mice [108,109]. All together these reports confirmed the critical role of direct and indirect antioxidant proteins, which are under the control of $\mathrm{Nrf} 2$, for cytoprotection against divergent arrays of oxidative damage. 


\section{Indirect Antioxidants Activating the Nrf2 System}

Given that Nrf2 primarily governs the expression of antioxidant genes, activation of Nrf2 signaling by specific chemicals can be conceded as one of effective means for prevention of oxidative injuries. In particular, naturally occurring chemicals from vegetables and fruits have been recognized to exhibit antioxidant, ROS-eliminating properties. $\beta$-Carotene is an example of direct antioxidants, while various phytochemicals exert their antioxidant activity through Nrf2 signaling. As recently reviewed by Surh et al. [110], phytochemicals activating Nrf2 signaling include isothiocyanates, dithiolethiones, resveratrol, curcumin, CAPE (caffeic acid phenethyl ester; from honeybee hives), epigallicatechin gallate (from green tea), allyl sulfides (from garlic), xanthohumols (from hop), and cinnamaldehyde. The beneficial effects of these phytochemicals have been demonstrated by numerous studies, and in particular, cancer preventive efficacy has been highlighted in many animal and human studies (Table 2).

Table 2. Indirect antioxidants and their effects on chemical toxicity.

\begin{tabular}{|c|c|}
\hline Indirect antioxidants & Effect on target organ toxicity \\
\hline Sulforaphane & $\begin{array}{l}\text { Protection against tumor formation induced by } \\
\text { many carcinogens: mammary, colon, lung, } \\
\text { pancreatic, gastric, intestine, skin, and bladder } \\
\text { (mouse, rat, hamster) [16, 111-115] }\end{array}$ \\
\hline D3T & $\begin{array}{l}\text { Inhibition of aflatoxin } B_{1} \text { induced hepatic } \\
\text { tumorigenesis (rat) }[116,117] \text {. }\end{array}$ \\
\hline Oltipraz & $\begin{array}{l}\text { Inhibition of carcinogenesis induced by various } \\
\text { carcinogens in bladder, colon, kidney, liver, } \\
\text { lung, pancreas, and stomach (mouse, rat) [116, } \\
118,119] .\end{array}$ \\
\hline Resveratrol & $\begin{array}{l}\text { Inhibition of growth of variety tumors: skin, } \\
\text { breast, gastric, colon, small intestine, lung, } \\
\text { esophageal, prostate, liver, and pancreatic } \\
\text { cancers (mice, rat) [120-122]. } \\
\text { Human clinical trials in breast cancer patients } \\
\text { [123]. }\end{array}$ \\
\hline Curcumin & $\begin{array}{l}\text { Inhibition of tumor development in skin, liver, } \\
\text { oral, esophageal, stomach, intestinal, colon, and } \\
\text { bladder (mouse, rat) [124]. } \\
\text { Human clinical trials in patients with advanced } \\
\text { pancreatic cancer and other disease }[125,126] .\end{array}$ \\
\hline CAPE & $\begin{array}{l}\text { Anti-proliferation property in cancer cells } \\
\text { [127]. }\end{array}$ \\
\hline
\end{tabular}


The isothiocyanate sulforaphane (1-isothiocyanato-(4R)-(methylsulfinyl)butane) was isolated from broccoli by a bioassay screen of plant extracts for the identification of NQO1 inducers [128]. Accumulating lines of evidence show that sulforaphane is one of the most potent phase 2 enzyme inducers, and its indirect antioxidant properties have been demonstrated in various chemicalcarcinogenesis animal studies. In female Sprague Dawley rats, oral administration of sulforaphane with doses of 75,100 , or $150 \mu \mathrm{mol} /$ day for four days strongly inhibited tumor incidence, multiplicity, and burden by DMBA treatment [115]. In male Fisher rats treated with azoxymethane, sulforaphane inhibited the formation of colonic aberrant crypt foci [111]. Sulforaphane also inhibited lung adenomas induced by tobacco carcinogens [129] and suppressed the incidence of pancreatic tumors induced by $\mathrm{N}$-nitroso-bis(2-oxopropyl)amine. Further studies with $n r f 2-/-$ mice have revealed that Nrf2 is the molecular target of sulforaphane. Nrf2-deficient mice lost antioxidant gene inducibility following sulforaphane treatment, and did not show the protective effect of sulforaphane in a $\mathrm{B}[a] \mathrm{P}$-induced gastric tumor formation model [113].

Dithiolethiones including D3T and oltipraz are organosulfur compounds [130]. Oltipraz, a congener of D3T, was initially developed for the treatment of schistosomiasis and has been extensively studied as a typical cancer chemopreventive agent. In various rodent organs, such as bladder, colon, kidney, liver, lung, pancreas, stomach, trachea, and blood, oltipraz pre-treatment inhibited carcinogenesis induced by divergent carcinogens including azoxymethane, aflatoxin $\mathrm{B}_{1}$, and $\mathrm{B}[a] \mathrm{P}$ [116-118]. In addition, phase I and II clinical trials have demonstrated the cancer preventive efficacy of oltipraz in humans. A single dose of oltipraz $\left(125 \sim 1,000 \mathrm{mg} / \mathrm{m}^{2}\right)$ in humans increased enzymatic activity of NQO1, GCL, and GST in colonic mucosa [131]. NQO1 activity in peripheral mononuclear cells was also elevated in oltipraz-treated individuals without showing significant side effects. In a later randomized double-blind study in Qidong, People's Republic of China, the intake of low-dose oltipraz increased the phase 2 conjugation reaction of aflatoxin $\mathrm{B}_{1}$, indicating the facilitated detoxification of this potent carcinogen [132]. Anti-carcinogenic effects of dithiolethiones were found to be Nrf2dependent: the induction of antioxidant genes by dithiolethiones (D3T and oltipraz) was blunt and cancer preventive efficacy of oltipraz has been lost in $n r f 2$-deficient mice [50,52,58,104]. Keap1 has been proposed as the molecular target of dithiolethiones, and Wakabayashi et al. demonstrated that D3T led to intermolecular disulfide bond formation between Cys273 and Cys288 of two Keap1 proteins [91].

Resveratrol (3,5,4'-trihydroxystilbene) is a nonflavonoid polyphenol found in peanuts, grapes, and red wines [133]. Numerous studies have suggested that resveratrol in red wine can reduce the incidence of coronary heart disease and cancer [122]. Resveratrol has an intrinsic antioxidant property, which depends on the redox properties of phenolic hydroxyl groups [134], and its strong antioxidant properties were evidenced by the inhibition of polyunsaturated fatty acid oxidation, which is a core pathologic marker of atherosclerosis [135]. Recent reports showed that the protective effects of resveratrol are mediated by the activation of $\mathrm{Nrf2}$ : pretreatment with resveratrol protected $\mathrm{H}_{2} \mathrm{O}_{2}-$ induced PC12 cell death and this protection was accompanied by upregulation of HO-1 [136]. Resveratrol restored cigarette smoke-depleted GSH levels by upregulating GCL expression through Nrf2 in human lung epithelial cells, and protected cells against cigarette smoke-mediated oxidative stress [137]. Further, enzymatic activities of antioxidant enzymes such as NQO1, Gpx, GR, GST, and SOD were increased after pretreatment with resveratrol in cultured hepatocytes [138]. 
Curcumin (1,7-bis(4-hydroxy-3-methoxyphenyl)-1,6-heptadiene-3,5-dione) is a major yellow pigment naturally isolated from the rhizomes of Curcuma longa and used as a coloring and flavoring agent [139]. Curcumin has various beneficial properties including anti-inflammatory, antioxidant, and chemopreventive activities $[122,126]$. Curcumin elevated enzymatic activity and protein levels of HO1 through Nrf2 signaling in porcine renal epithelial proximal tubule cells (LLC-PK1) [140]. Dietary administration of curcumin in mice increased nuclear Nrf2, ARE binding activity, and target gene expression in the liver and lungs. As a consequence, curcumin-treated mice showed significantly reduced DNA adduct formation, oxidative damage, and inflammation following B[a]P challenge [141].

\section{Pleiotropic Effects of Small Molecule Nrf2 Activators}

Health benefits of statins in reducing cardiovascular risk are not solely dependent on their cholesterol-lowering effects: basic and clinical studies have demonstrated that the inhibition of inflammation, maintenance of endothelial function, and modulation of platelet function cooperatively contribute to the protective effect of statins [142, 143]. Based on this concept, it has been widely speculated that the use of statins can prevent/ameliorate stroke, Alzheimer's and renal diseases, and cancers [143-145]. Recent advances in understanding the mechanism of action of statins suggest that these non-cholesterol beneficial effects can be explained by a single mechanism inhibiting 3-hydroxy-3methylglutaryl coenzyme A (HMG CoA reductase) and the consequent reduction in isoprenoids, which are essential for the posttranslational modification of several signaling proteins. Small molecule Nrf2 activators already gained attention for their cancer preventive efficacy. However, recent understanding of the gene clusters regulated by Nrf2 and its various pathophysiological implications provided in-depth characterization of $\mathrm{Nrf} 2$ signaling, indicating the pleiotropic effects of Nrf2 activators.

\subsection{Anti-Inflammatory Function of Small Molecule Nrf2 Activators}

Considerable evidence supports the notion that Nrf2 activation can suppress the inflammatory response although its mechanism has not been fully defined. As increased ROS generation is a core event of inflammation, enhanced cellular antioxidant capacity is believed to contribute to the repression of inflammatory injuries. In particular, potent anti-inflammatory function of HO-1 has been highlighted: increased carbon monoxide, an inhibitor of macrophage activity, is thought to participate in the anti-inflammatory role of HO-1 $[35,146,147]$. Consistent with these reports, a number of studies have shown that indirect antioxidant-mediated Nrf2 activation is strongly associated with the protection of animals from pro-inflammatory insults [148]. Indeed, a potent Nrf2 activator synthetic triterpenoid significantly reduced LPS-induced cytokine production and in turn suppressed mortality by LPS in wild-type mice; however these protective effects were not observed in nrf2-null mice [106]. In the context of chronic inflammation and its causal link to carcinogenesis, the anti-inflammatory role of small molecule Nrf2 activators appears to be one of mechanisms of cancer-preventive action. 


\subsection{Modulation of Proteasome Function by Nrf2 Activators: Implication in Protein Toxicity-} Associated Diseases

A comparative global gene expression analysis in $n r f 2-/-$ mice led to the identification of multiple subunits of hepatic $26 \mathrm{~S}$ proteasome as D3T-inducible, Nrf2-dependent genes [58]. In a subsequent study, it was shown that the expression of Psmb5, which is the catalytic core subunit of the $20 \mathrm{~S}$ proteasome, can be up-regulated by proximal AREs [149]. In addition to increased expression of individual subunits, total enzymatic activity of the proteasome was significantly enhanced in multiple tissues from D3T-treated mice including liver, lung, kidney, and small intestines [150]. Since the proteasome, the 20S proteasome in particular, is known to be largely responsible for the degradation of oxidatively damaged proteins, under conditions with abnormal proteasome function, cells will be encountered by condition termed protein toxicity [151-153]. This protein toxicity has been highlighted in neurodegenerative diseases such as Alzheimer's disease and amyotrophic lateral sclerosis. Therefore, the use of Nrf2 activators may prevent protein toxicity by maintaining proteasome function. In fact, sulforaphane treatment ameliorated hydrogen peroxide-induced protein oxidation and resulted cytotoxicity by modulating proteasome expression in murine neuroblastoma cells [154]. Degradation of SOD1 G93A protein, which has been postulated as an ALS-causing mutant protein, was facilitated in tissue homogenates from D3T-treated mice [150].

\subsection{Lipid Metabolism and Nrf2 Activators.}

Several recent findings indicated a potential role for Nrf2 in lipid metabolism. For instance, Shin et al., reported that $n r f 2-n u l l$ MEFs showed markedly accelerated adipogenesis, which was triggered by rosiglitazone treatment, compared to wild-type MEFs [155]. In these cells, treatment with an Nrf2activating triterpenoid effectively inhibited adipocyte differentiation; however nrf2-null cells were unaffected by triterpenoid. In a follow-up study, another synthetic triterpenoid 1-[2-cyano-3-,12-dioxooleana-1,9(11)-dien-28-oyl]imidazole (CDDO-Im) completely prevented the increase in weight gain of wild-type mice imparted by a high-fat diet, whereas $n r f 2$-disrupted mice were not responsive to the preventive intervention of CDDO-Im [156]. Similar findings have been reported by Tanaka et al., and concentrations of free fatty acid and malondialdehyde equivalents were higher in $n r f 2$-null mice compared with wild-type mice after four weeks on a high-fat diet [157].

\subsection{Liver Regeneration and Nrf2}

Another promising effect of Nrf2 activators is their potential role in liver regeneration after injury. A recent study by Beyer et al. demonstrated that liver regeneration after a partial hepatectomy is significantly delayed in nrf2-null mice compared to wild-type mice [158]. This finding has been explained by the observation that increased oxidative stress in the $n r f 2$-null condition can lead to insulin/insulin-like growth factor resistance and further impairment of p38 MAPK and AKT signaling, which is necessary for liver cell proliferation [159]. A similar finding was reported by Wakabayashi et al.; however, this group highlighted the direct role of Nrf2 in the regulation of Notch1, suggesting that a loss of $n r f 2$ impedes Notch function and thereby interferes with liver cell proliferation [160]. These results suggest that Nrf2 activators may have beneficial effects in recovery from liver damage, which 
can result from chronic alcohol consumption, chemical toxins, and drug/viral inflammation. In fact, this possibility has been supported by Kang et al.: oltipraz treatment of rats with established cirrhotic liver enhanced regeneration and reduced cirrhotic nodules with a concomitant improvement in survival $[161,162]$. Although the authors concluded that activation of CCAAT/enhancer binding protein $\beta$ $(\mathrm{C} / \mathrm{EBP} \beta)$ and a consequent suppression of TGF $\beta$ expression is a primary mechanism of oltiprazmediated regeneration, the potential involvement of Nrf2 signaling may be of interest for future investigations.

\section{Conclusions}

The utility of direct antioxidants has been confronted by several randomized clinical studies showing that vitamins $\mathrm{C}, \mathrm{E}$, and $\beta$-carotene do not reduce cancer incidence in humans. In addition, due to their short half-lives, direct antioxidants need to be administered frequently and relatively high dosages are required to sustain their physiological efficacy. Indirect antioxidants are defined as small molecules that can upregulate the expression of genes encoding antioxidant proteins through Nrf2. Eventually, this effect influences the physiological, biochemical, and/or cellular processes that inactivate free radicals or that prevent free radical-initiated chemical reactions. In contrast to the short half-life of direct antioxidants, indirect antioxidants act through gene regulation, so their physiological effects last longer than do those of direct antioxidants. Furthermore, indirect antioxidants are unlikely to evoke pro-oxidant effects, which have been a problem in the use of high dose vitamin E therapy. Of note, accumulating lines of evidence suggest that small molecule Nrf2 activators exert pleiotropic effects: prevention of cancer, amelioration of inflammatory injuries, protection against protein toxicity, promotion of liver regeneration after injuries, and maintenance of balanced lipid metabolism.

As for the development of indirect antioxidants, Keap1 is now accepted as a direct molecular target of antioxidant gene inducers. However, at this time, due to the limited understanding of the structural biology of Keap-Nrf2 proteins, the detailed mechanism of how specific chemicals react with specific sulfhydryl residues of the Keap1 protein remains to be uncovered. In general, inducers of antioxidant genes are diverse in their structures and chemical properties; however, one common feature is the high reactivity to sulfhydryl groups through the oxidation or alkylation reaction. Originally, Paul Talalay and colleagues defined 9 different chemical classes of sulfhydryl-reactive gene inducers, including isothiocyanates, dithiolethiones, a variety of Michael reaction acceptors, arsenicals and heavy metals, hydroperoxides, vicinal dimercaptans, oxidized diphenols, phenylene diamines, and quinones [163]. A recent study by Kobayashi et al., developed a zebrafish model of a Keap1 mutation, and classified several sulfhydryl reactive chemicals into distinct categories depending on the reactive cysteine residues required for their action [164]. In their classification, sulforaphane, D3T, and GSH depletor diethylmaleate are classified into the same class based on the requirement of Cys151 for Nrf2 activation, while Prostaglandin $\mathrm{A}_{2}$ and 15-deoxy- $\Delta^{12,14}$-prostaglandin $\mathrm{J}_{2}$, in a different class, require Cys273 for their action. On the other hand, an independent study reported that hydrogen peroxide modified multiple cysteine residues of Keap1, including Cys77, Cys297, Cys319, Cys369, and Cys434, indicating more nonspecific modifications in this case [165]. These suggest a clear notion that particular cysteine residues of the Keap1 protein respond to differential signals in a specific way. Therefore, an accurate understanding of the cysteine reactivity of the Keap1 protein will promote the 
development of more specific antioxidants for the activation of Nrf2. In conclusion, we propose that the development of specific small molecule Nrf2 activators might be a successful strategy to control or prevent a wide array human disease, which is associated with oxidative injuries.

\section{Acknowledgements}

This work was supported by the National Research Foundation of Korea Grant (2010-0013857 and 2010-0016808) funded by the Korean government.

\section{References}

1. Fridovich, I. Superoxide radical and superoxide dismutases. Annu. Rev. Biochem. 1995, 64, 97-112.

2. Pacher, P.; Beckman, J.S.; Liaudet, L. Nitric oxide and peroxynitrite in health and disease. Physiol. Rev. 2007, 87, 315-424.

3. Halliwell B, G.J.; Free Radicals in Biology and Medicine, 3rd ed.; Oxford University Press: New York, NY, USA, 2001; pp. 82-95.

4. Steinbrenner, H.; Sies, H. Protection against reactive oxygen species by selenoproteins. Biochim. Biophys. Acta 2009, 1790, 1478-1485.

5. Halliwell B, G.J.; Free Radicals in Biology and Medicine, 3rd ed.; Oxford University Press: New York, NY, USA, 2001; pp. 262-316

6. Szatrowski, T.P.; Nathan, C.F. Production of large amounts of hydrogen peroxide by human tumor cells. Cancer Res. 1991, 51, 794-798.

7. Fita, I.; Rossmann, M.G. The active center of catalase. J. Mol. Biol. 1985, 185, 21-37.

8. Schneider, Y.; Vincent, F.; Duranton, B.; Badolo, L.; Gosse, F.; Bergmann, C.; Seiler, N.; Raul, F. Anti-proliferative effect of resveratrol, a natural component of grapes and wine, on human colonic cancer cells. Cancer Lett. 2000, 158, 85-91.

9. Brigelius-Flohe, R. Tissue-specific functions of individual glutathione peroxidases. Free Radic. Biol. Med. 1999, 27, 951-965.

10. Forgione, M.A.; Cap, A.; Liao, R.; Moldovan, N.I.; Eberhardt, R.T.; Lim, C.C.; Jones, J.; Goldschmidt-Clermont, P.J.; Loscalzo, J. Heterozygous cellular glutathione peroxidase deficiency in the mouse: abnormalities in vascular and cardiac function and structure. Circulation 2002, 106, 1154-1158.

11. Meister, A.; Anderson, M.E. Glutathione. Annu. Rev. Biochem.1983, 52, 711-760.

12. Rahman, I.; Biswas, S.K.; Jimenez, L.A.; Torres, M.; Forman, H.J. Glutathione, stress responses, and redox signaling in lung inflammation. Antioxid. Redox. Signal 2005, 7, 42-59.

13. Huang, C.S.; Chang, L.S.; Anderson, M.E.; Meister, A. Catalytic and regulatory properties of the heavy subunit of rat kidney gamma-glutamylcysteine synthetase. J. Biol. Chem. 1993, 268, 19675-19680.

14. Thannickal, V.J.; Fanburg, B.L. Reactive oxygen species in cell signaling. Am. J. Physiol. Lung. Cell Mol. Physiol. 2000, 279, L1005-1028.

15. Conney, A.H. Induction of drug-metabolizing enzymes: a path to the discovery of multiple cytochromes P450. Annu. Rev. Pharmacol. Toxicol. 2003, 43, 1-30. 
16. Dinkova-Kostova, A.T.; Talalay, P. Direct and indirect antioxidant properties of inducers of cytoprotective proteins. Mol. Nutr. Food Res. 2008, 52 (Suppl. 1), S128-S138.

17. Hayes, J.D.; McMahon, M.; Chowdhry, S.; Dinkova-Kostova, A.T. Cancer Chemoprevention Mechanisms Mediated Through the Keap1-Nrf2 Pathway. Antioxid. Redox. Signal 2010, in press.

18. Jernstrom, B.; Dock, L.; Martinez, M. Metabolic activation of benzoa.pyrene-7,8-dihydrodiol and benzoa.pyrene-7,8-dihydrodiol-9,10-epoxide to protein-binding products and the inhibitory effect of glutathione and cysteine. Carcinogenesis 1984, 5, 199-204.

19. Hayes, J.D.; Flanagan, J.U.; Jowsey, I.R. Glutathione transferases. Annu. Rev. Pharmacol. Toxicol. 2005, 45, 51-88.

20. Henderson, C.J.; Smith, A.G.; Ure, J.; Brown, K.; Bacon, E.J.; Wolf, C.R. Increased skin tumorigenesis in mice lacking pi class glutathione S-transferases. Proc. Natl. Acad. Sci. USA 1998, 95, 5275-5280.

21. Ritchie, K.J.; Henderson, C.J.; Wang, X.J.; Vassieva, O.; Carrie, D.; Farmer, P.B.; Gaskell, M.; Park, K.; Wolf, C.R. Glutathione transferase pi plays a critical role in the development of lung carcinogenesis following exposure to tobacco-related carcinogens and urethane. Cancer Res.. 2007, 67, 9248-9257.

22 Nazar-Stewart, V.; Vaughan, T.L.; Burt, R.D.; Chen, C.; Berwick, M.; Swanson, G.M. Glutathione S-transferase M1 and susceptibility to nasopharyngeal carcinoma. Cancer Epidemiol. Biomarkers Prev. 1999, 8, 547-551.

23. Tukey, R.H.; Strassburg, C.P. Human UDP-glucuronosyltransferases: metabolism, expression, and disease. Annu. Rev. Pharmacol. Toxicol. 2000, 40, 581-616.

24. Vienneau, D.S.; DeBoni, U.; Wells, P.G. Potential genoprotective role for UDPglucuronosyltransferases in chemical carcinogenesis: initiation of micronuclei by benzo(a)pyrene and benzo(e)pyrene in UDP-glucuronosyltransferase-deficient cultured rat skin fibroblasts. Cancer Res. 1995, 55, 1045-1051.

25. Leung, H.Y.; Wang, Y.; Leung, L.K. Differential effect of over-expressing UGT1A1 and CYP1A1 on xenobiotic assault in MCF-7 cells. Toxicology 2007, 242, 153-159.

26. Nioi, P.; Hayes, J.D. Contribution of $\mathrm{NAD}(\mathrm{P}) \mathrm{H}$ :quinone oxidoreductase 1 to protection against carcinogenesis, and regulation of its gene by the Nrf2 basic-region leucine zipper and the arylhydrocarbon receptor basic helix-loop-helix transcription factors. Mutat. Res. 2004, 555, 149-171.

27. Beyer, R.E.; Segura-Aguilar, J.; Di Bernardo, S.; Cavazzoni, M.; Fato, R.; Fiorentini, D.; Galli, M.C.; Setti, M.; Landi, L.; Lenaz, G. The role of DT-diaphorase in the maintenance of the reduced antioxidant form of coenzyme Q in membrane systems. Proc. Natl. Acad. Sci. USA 1996, 93, 2528-2532.

28. Landi, L.; Fiorentini, D.; Galli, M.C.; Segura-Aguilar, J.; Beyer, R.E. DT-Diaphorase maintains the reduced state of ubiquinones in lipid vesicles thereby promoting their antioxidant function. Free Radic. Biol. Med. 1997, 22, 329-335.

29. Siegel, D.; Bolton, E.M.; Burr, J.A.; Liebler, D.C.; Ross, D. The reduction of alphatocopherolquinone by human $\mathrm{NAD}(\mathrm{P}) \mathrm{H}$ : quinone oxidoreductase: the role of alphatocopherolhydroquinone as a cellular antioxidant. Mol. Pharmacol. 1997, 52, 300-305. 
30. Long, D.J., 2nd; Waikel, R.L.; Wang, X.J.; Perlaky, L.; Roop, D.R.; Jaiswal, A.K. $\mathrm{NAD}(\mathrm{P}) \mathrm{H}$ :quinone oxidoreductase 1 deficiency increases susceptibility to benzo(a)pyreneinduced mouse skin carcinogenesis. Cancer Res. 2000, 60, 5913-5915.

31. Traver, R.D.; Siegel, D.; Beall, H.D.; Phillips, R.M.; Gibson, N.W.; Franklin, W.A.; Ross, D. Characterization of a polymorphism in $\mathrm{NAD}(\mathrm{P}) \mathrm{H}$ : quinone oxidoreductase (DT-diaphorase). $\mathrm{Br}$. J. Cancer 1997, 75, 69-75.

32. Wiemels, J.L.; Pagnamenta, A.; Taylor, G.M.; Eden, O.B.; Alexander, F.E.; Greaves, M.F. A lack of a functional $\mathrm{NAD}(\mathrm{P}) \mathrm{H}$ :quinone oxidoreductase allele is selectively associated with pediatric leukemias that have MLL fusions. United Kingdom Childhood Cancer Study Investigators. Cancer Res. 1999, 59, 4095-4099.

33. Lafuente, M.J.; Casterad, X.; Trias, M.; Ascaso, C.; Molina, R.; Ballesta, A.; Zheng, S.; Wiencke, J.K.; Lafuente, A. NAD(P)H:quinone oxidoreductase-dependent risk for colorectal cancer and its association with the presence of K-ras mutations in tumors. Carcinogenesis 2000, 21, 1813-1819.

34. Zhang, J.H.; Li, Y.; Wang, R.; Sarbia, M.; Guo, W.; Wen, D.G.; Wei, L.Z.; Chen, Z.F.; Kuang, G.; Zhang, L.W.; He, M.; Wu, M.L.; Wang, S.J. The NAD(P)H: quinone oxidoreductase 1 C609T polymorphism and susceptibility to esophageal cancer.. Zhonghua Yi Xue Yi Chuan Xue Za Zhi 2003, 20, 544-546.

35. Loboda, A.; Jazwa, A.; Grochot-Przeczek, A.; Rutkowski, A.J.; Cisowski, J.; Agarwal, A.; Jozkowicz, A.; Dulak, J. Heme oxygenase-1 and the vascular bed: from molecular mechanisms to therapeutic opportunities. Antioxid. Redox Signal 2008, 10, 1767-1812.

36. Prestera, T.; Talalay, P.; Alam, J.; Ahn, Y.I.; Lee, P.J.; Choi, A.M. Parallel induction of heme oxygenase- 1 and chemoprotective phase 2 enzymes by electrophiles and antioxidants: regulation by upstream antioxidant-responsive elements (ARE). Mol. Med. 1995, 1, 827-837.

37. Harrison, P.M.; Arosio, P. The ferritins: molecular properties, iron storage function and cellular regulation. Biochim. Biophys. Acta 1996, 1275, 161-203.

38. Tsuji, Y.; Ayaki, H.; Whitman, S.P.; Morrow, C.S.; Torti, S.V.; Torti, F.M. Coordinate transcriptional and translational regulation of ferritin in response to oxidative stress. Mol. Cell Biol. 2000, 20, 5818-5827.

39. Rushmore, T.H.; Pickett, C.B. Transcriptional regulation of the rat glutathione S-transferase Ya subunit gene. Characterization of a xenobiotic-responsive element controlling inducible expression by phenolic antioxidants. J. Biol. Chem. 1990, 265, 14648-14653.

40. Rushmore, T.H.; Morton, M.R.; Pickett, C.B. The antioxidant responsive element. Activation by oxidative stress and identification of the DNA consensus sequence required for functional activity. J. Biol. Chem. 1991, 266, 11632-11639.

41. Favreau, L.V.; Pickett, C.B. Transcriptional regulation of the rat NAD(P)H:quinone reductase gene. Identification of regulatory elements controlling basal level expression and inducible expression by planar aromatic compounds and phenolic antioxidants. J. Biol. Chem. 1991, 266, 4556-4561.

42. Nioi, P.; McMahon, M.; Itoh, K.; Yamamoto, M.; Hayes, J.D. Identification of a novel Nrf2regulated antioxidant response element (ARE) in the mouse $\mathrm{NAD}(\mathrm{P}) \mathrm{H}$ :quinone oxidoreductase 1 gene: reassessment of the ARE consensus sequence. Biochem. J. 2003, 374, 337-348. 
43. Jaiswal, A.K. Human NAD(P)H:quinone oxidoreductase (NQO1) gene structure and induction by dioxin. Biochemistry 1991, 30, 10647-10653.

44. Erickson, A.M.; Nevarea, Z.; Gipp, J.J.; Mulcahy, R.T. Identification of a variant antioxidant response element in the promoter of the human glutamate-cysteine ligase modifier subunit gene. Revision of the ARE consensus sequence. J. Biol. Chem. 2002, 277, 30730-30737.

45. Mulcahy, R.T.; Gipp, J.J. Identification of a putative antioxidant response element in the 5'flanking region of the human gamma-glutamylcysteine synthetase heavy subunit gene. Biochem. Biophys. Res. Commun. 1995, 209, 227-233.

46. Mulcahy, R.T.; Wartman, M.A.; Bailey, H.H.; Gipp, J.J. Constitutive and beta-naphthoflavoneinduced expression of the human gamma-glutamylcysteine synthetase heavy subunit gene is regulated by a distal antioxidant response element/TRE sequence. J. Biol. Chem. 1997, 272, 7445-7454.

47. Wasserman, W.W.; Fahl, W.E. Functional antioxidant responsive elements. Proc. Natl. Acad. Sci. USA 1997, 94, 5361-5366.

48. Itoh, K.; Chiba, T.; Takahashi, S.; Ishii, T.; Igarashi, K.; Katoh, Y.; Oyake, T.; Hayashi, N.; Satoh, K.; Hatayama, I.; Yamamoto, M.; Nabeshima, Y. An Nrf2/small Maf heterodimer mediates the induction of phase II detoxifying enzyme genes through antioxidant response elements. Biochem. Biophys. Res. Commun. 1997, 236, 313-322.

49. Kobayashi, M.; Yamamoto, M. Molecular mechanisms activating the Nrf2-Keap1 pathway of antioxidant gene regulation. Antioxid. Redox Signal 2005, 7, 385-394.

50. Kwak, M.K.; Egner, P.A.; Dolan, P.M.; Ramos-Gomez, M.; Groopman, J.D.; Itoh, K.; Yamamoto, M.; Kensler, T.W. Role of phase 2 enzyme induction in chemoprotection by dithiolethiones. Mutat. Res. 2001, 480-481, 305-315.

51. Venugopal, R.; Jaiswal, A.K. Nrf1 and Nrf2 positively and c-Fos and Fra1 negatively regulate the human antioxidant response element-mediated expression of $\mathrm{NAD}(\mathrm{P}) \mathrm{H}$ :quinone oxidoreductase 1 gene. Proc. Natl. Acad. Sci. USA 1996, 93, 14960-14965.

52. Ramos-Gomez, M.; Kwak, M.K.; Dolan, P.M.; Itoh, K.; Yamamoto, M.; Talalay, P.; Kensler, T.W. Sensitivity to carcinogenesis is increased and chemoprotective efficacy of enzyme inducers is lost in nrf2 transcription factor-deficient mice. Proc. Natl. Acad. Sci. USA 2001, 98, 3410-3415.

53. Alam, J.; Stewart, D.; Touchard, C.; Boinapally, S.; Choi, A.M.; Cook, J.L. Nrf2, a Cap'n'Collar transcription factor, regulates induction of the heme oxygenase-1 gene. J. Biol. Chem. 1999, 274, 26071-26078.

54. He, C.H.; Gong, P.; Hu, B.; Stewart, D.; Choi, M.E.; Choi, A.M.; Alam, J. Identification of activating transcription factor 4 (ATF4) as an Nrf2-interacting protein. Implication for heme oxygenase-1 gene regulation. J. Biol. Chem. 2001, 276, 20858-20865.

55. Igarashi, K.; Kataoka, K.; Itoh, K.; Hayashi, N.; Nishizawa, M.; Yamamoto, M. Regulation of transcription by dimerization of erythroid factor NF-E2 p45 with small Maf proteins. Nature 1994, 367, 568-572.

56. Katsuoka, F.; Motohashi, H.; Ishii, T.; Aburatani, H.; Engel, J.D.; Yamamoto, M. Genetic evidence that small maf proteins are essential for the activation of antioxidant response elementdependent genes. Mol. Cell Biol. 2005, 25, 8044-8051. 
57. Motohashi, H.; O'Connor, T.; Katsuoka, F.; Engel, J.D.; Yamamoto, M. Integration and diversity of the regulatory network composed of Maf and $\mathrm{CNC}$ families of transcription factors. Gene 2002, 294, 1-12.

58. Kwak, M.K.; Wakabayashi, N.; Itoh, K.; Motohashi, H.; Yamamoto, M.; Kensler, T.W. Modulation of gene expression by cancer chemopreventive dithiolethiones through the Keap1Nrf2 pathway. Identification of novel gene clusters for cell survival. J. Biol. Chem. 2003, 278, 8135-8145.

59. Hu, R.; Xu, C.; Shen, G.; Jain, M.R.; Khor, T.O.; Gopalkrishnan, A.; Lin, W.; Reddy, B.; Chan, J.Y.; Kong, A.N. Gene expression profiles induced by cancer chemopreventive isothiocyanate sulforaphane in the liver of C57BL/6J mice and C57BL/6J/Nrf2 (-/-) mice. Cancer Lett. 2006, 243, 170-192.

60. Hu, R.; Xu, C.; Shen, G.; Jain, M.R.; Khor, T.O.; Gopalkrishnan, A.; Lin, W.; Reddy, B.; Chan, J.Y.; Kong, A.N. Identification of Nrf2-regulated genes induced by chemopreventive isothiocyanate PEITC by oligonucleotide microarray. Life Sci. 2006, 79, 1944-1955.

61. Kwak, M.K.; Kensler, T.W. Targeting NRF2 signaling for cancer chemoprevention. Toxicol. Appl. Pharmacol. 2010, 244, 66-76.

62. Lee, J.M.; Calkins, M.J.; Chan, K.; Kan, Y.W.; Johnson, J.A. Identification of the NF-E2-related factor-2-dependent genes conferring protection against oxidative stress in primary cortical astrocytes using oligonucleotide microarray analysis. J. Biol. Chem. 2003, 278, 12029-12038.

63. Nair, S.; Xu, C.; Shen, G.; Hebbar, V.; Gopalakrishnan, A.; Hu, R.; Jain, M.R.; Lin, W.; Keum, Y.S.; Liew, C.; Chan, J.Y.; Kong, A.N. Pharmacogenomics of phenolic antioxidant butylated hydroxyanisole (BHA) in the small intestine and liver of Nrf2 knockout and C57BL/6J mice. Pharm. Res. 2006, 23, 2621-2637.

64. Thimmulappa, R.K.; Mai, K.H.; Srisuma, S.; Kensler, T.W.; Yamamoto, M.; Biswal, S. Identification of Nrf2-regulated genes induced by the chemopreventive agent sulforaphane by oligonucleotide microarray. Cancer Res. 2002, 62, 5196-5203.

65. Yates, M.S.; Kwak, M.K.; Egner, P.A.; Groopman, J.D.; Bodreddigari, S.; Sutter, T.R.; Baumgartner, K.J.; Roebuck, B.D.; Liby, K.T.; Yore, M.M.; Honda, T.; Gribble, G.W.; Sporn, M.B.; Kensler, T.W. Potent protection against aflatoxin-induced tumorigenesis through induction of Nrf2-regulated pathways by the triterpenoid 1-2-cyano-3-,12-dioxooleana-1,9(11)-dien-28oyl.imidazole. Cancer Res. 2006, 66, 2488-2494.

66. Yates, M.S.; Tran, Q.T.; Dolan, P.M.; Osburn, W.O.; Shin, S.; McCulloch, C.C.; Silkworth, J.B.; Taguchi, K.; Yamamoto, M.; Williams, C.R.; Liby, K.T.; Sporn, M.B.; Sutter, T.R.; Kensler, T.W. Genetic versus Chemoprotective Activation of Nrf2 Signaling: Overlapping yet Distinct Gene Expression Profiles between Keap1 Knockout and Triterpenoid Treated Mice. Carcinogenesis 2009, 2488-2494.

67. Rangasamy, T.; Cho, C.Y.; Thimmulappa, R.K.; Zhen, L.; Srisuma, S.S.; Kensler, T.W.; Yamamoto, M.; Petrache, I.; Tuder, R.M.; Biswal, S. Genetic ablation of Nrf2 enhances susceptibility to cigarette smoke-induced emphysema in mice. J. Clin. Invest. 2004, 114, 1248-1259.

68. MacLeod, A.K.; McMahon, M.; Plummer, S.M.; Higgins, L.G.; Penning, T.M.; Igarashi, K.; Hayes, J.D. Characterization of the cancer chemopreventive NRF2-dependent gene battery in 
human keratinocytes: demonstration that the KEAP1-NRF2 pathway, and not the BACH1-NRF2 pathway, controls cytoprotection against electrophiles as well as redox-cycling compounds. Carcinogenesis 2009, 30, 1571-1580.

69. Li, J.; Lee, J.M.; Johnson, J.A. Microarray analysis reveals an antioxidant responsive elementdriven gene set involved in conferring protection from an oxidative stress-induced apoptosis in IMR-32 cells. J. Biol. Chem. 2002, 277, 388-394.

70. Harvey, C.J.; Thimmulappa, R.K.; Singh, A.; Blake, D.J.; Ling, G.; Wakabayashi, N.; Fujii, J.; Myers, A.; Biswal, S. Nrf2-regulated glutathione recycling independent of biosynthesis is critical for cell survival during oxidative stress. Free Radic. Biol. Med. 2009, 46, 443-453.

71. Reisman, S.A.; Yeager, R.L.; Yamamoto, M.; Klaassen, C.D. Increased Nrf2 activation in livers from Keap1-knockdown mice increases expression of cytoprotective genes that detoxify electrophiles more than those that detoxify reactive oxygen species. Toxicol. Sci. 2009, 108, 35-47.

72. Singh, A.; Rangasamy, T.; Thimmulappa, R.K.; Lee, H.; Osburn, W.O.; Brigelius-Flohe, R.; Kensler, T.W.; Yamamoto, M.; Biswal, S. Glutathione peroxidase 2, the major cigarette smokeinducible isoform of GPX in lungs, is regulated by Nrf2. Am. J. Respir. Cell Mol. Biol. 2006, 35, 639-650.

73. Cho, H.Y.; Reddy, S.P.; Debiase, A.; Yamamoto, M.; Kleeberger, S.R. Gene expression profiling of NRF2-mediated protection against oxidative injury. Free Radic. Biol. Med. 2005, 38, 325-343.

74. Okawa, H.; Motohashi, H.; Kobayashi, A.; Aburatani, H.; Kensler, T.W.; Yamamoto, M. Hepatocyte-specific deletion of the keap1 gene activates $\mathrm{Nrf} 2$ and confers potent resistance against acute drug toxicity. Biochem. Biophys. Res. Commun. 2006, 339, 79-88.

75. Banning, A.; Deubel, S.; Kluth, D.; Zhou, Z.; Brigelius-Flohe, R. The GI-GPx gene is a target for Nrf2. Mol. Cell Biol. 2005, 25, 4914-4923.

76. Habeos, I.G.; Ziros, P.G.; Chartoumpekis, D.; Psyrogiannis, A.; Kyriazopoulou, V.; Papavassiliou, A.G. Simvastatin activates Keap1/Nrf2 signaling in rat liver. J Mol. Med. 2008, 86, 1279-1285.

77. Chowdhury, I.; Mo, Y.; Gao, L.; Kazi, A.; Fisher, A.B.; Feinstein, S.I. Oxidant stress stimulates expression of the human peroxiredoxin 6 gene by a transcriptional mechanism involving an antioxidant response element. Free Radic. Biol. Med. 2009, 46, 146-153.

78. Yeh, C.T.; Yen, G.C. Effect of sulforaphane on metallothionein expression and induction of apoptosis in human hepatoma HepG2 cells. Carcinogenesis 2005, 26, 2138-2148.

79. Mahaffey, C.M.; Zhang, H.; Rinna, A.; Holland, W.; Mack, P.C.; Forman, H.J. Multidrugresistant protein-3 gene regulation by the transcription factor Nrf2 in human bronchial epithelial and non-small-cell lung carcinoma. Free Radic. Biol. Med. 2009, 46, 1650-1657.

80. Itoh, K.; Igarashi, K.; Hayashi, N.; Nishizawa, M.; Yamamoto, M. Cloning and characterization of a novel erythroid cell-derived CNC family transcription factor heterodimerizing with the small Maf family proteins. Mol. Cell Biol. 1995, 15, 4184-4193.

81. Katoh, Y.; Itoh, K.; Yoshida, E.; Miyagishi, M.; Fukamizu, A.; Yamamoto, M. Two domains of Nrf2 cooperatively bind CBP, a CREB binding protein, and synergistically activate transcription. Genes Cells 2001, 6, 857-868. 
82. Nioi, P.; Nguyen, T.; Sherratt, P.J.; Pickett, C.B. The carboxy-terminal Neh3 domain of Nrf2 is required for transcriptional activation. Mol. Cell Biol. 2005, 25, 10895-10906.

83. Itoh, K.; Wakabayashi, N.; Katoh, Y.; Ishii, T.; Igarashi, K.; Engel, J.D.; Yamamoto, M. Keap1 represses nuclear activation of antioxidant responsive elements by Nrf2 through binding to the amino-terminal Neh2 domain. Genes Dev. 1999, 13, 76-86.

84. Xue, F.; Cooley, L. kelch encodes a component of intercellular bridges in Drosophila egg chambers. Cell 1993, 72, 681-693.

85. Kobayashi, A.; Kang, M.I.; Okawa, H.; Ohtsuji, M.; Zenke, Y.; Chiba, T.; Igarashi, K.; Yamamoto, M. Oxidative stress sensor Keap1 functions as an adaptor for Cul3-based E3 ligase to regulate proteasomal degradation of Nrf2. Mol. Cell Biol. 2004, 24, 7130-7139.

86. McMahon, M.; Thomas, N.; Itoh, K.; Yamamoto, M.; Hayes, J.D. Dimerization of substrate adaptors can facilitate cullin-mediated ubiquitylation of proteins by a "tethering" mechanism: a two-site interaction model for the Nrf2-Keap1 complex. J. Biol. Chem. 2006, 281, 24756-24768.

87. Zhang, D.D.; Lo, S.C.; Cross, J.V.; Templeton, D.J.; Hannink, M. Keap1 is a redox-regulated substrate adaptor protein for a Cul3-dependent ubiquitin ligase complex. Mol. Cell Biol. 2004, 24, 10941-10953.

88. Tong, K.I.; Kobayashi, A.; Katsuoka, F.; Yamamoto, M. Two-site substrate recognition model for the Keap1-Nrf2 system: a hinge and latch mechanism. Biol Chem 2006, 387, 1311-1320.

89. Tong, K.I.; Padmanabhan, B.; Kobayashi, A.; Shang, C.; Hirotsu, Y.; Yokoyama, S.; Yamamoto, M. Different electrostatic potentials define ETGE and DLG motifs as hinge and latch in oxidative stress response. Mol. Cell Biol. 2007, 27, 7511-7521.

90. Padmanabhan, B.; Tong, K.I.; Ohta, T.; Nakamura, Y.; Scharlock, M.; Ohtsuji, M.; Kang, M.I.; Kobayashi, A.; Yokoyama, S.; Yamamoto, M. Structural basis for defects of Keap1 activity provoked by its point mutations in lung cancer. Mol. Cell 2006, 21, 689-700.

91. Wakabayashi, N.; Dinkova-Kostova, A.T.; Holtzclaw, W.D.; Kang, M.L.; Kobayashi, A.; Yamamoto, M.; Kensler, T.W.; Talalay, P. Protection against electrophile and oxidant stress by induction of the phase 2 response: Fate of cysteines of the Keap1 sensor modified by inducers. Proc. Natl. Acad. Sci. USA 2004, 101, 2040-2045.

92. Dinkova-Kostova, A.T.; Holtzclaw, W.D.; Cole, R.N.; Itoh, K.; Wakabayashi, N.; Katoh, Y.; Yamamoto, M.; Talalay, P. Direct evidence that sulfhydryl groups of Keap1 are the sensors regulating induction of phase 2 enzymes that protect against carcinogens and oxidants. Proc. Natl. Acad. Sci. USA 2002, 99, 11908-11913.

93. Eggler, A.L.; Liu, G.; Pezzuto, J.M.; van Breemen, R.B.; Mesecar, A.D. Modifying specific cysteines of the electrophile-sensing human Keap1 protein is insufficient to disrupt binding to the Nrf2 domain Neh2. Proc. Natl. Acad. Sci. USA 2005, 102, 10070-10075.

94. Eggler, A.L.; Luo, Y.; van Breemen, R.B.; Mesecar, A.D. Identification of the highly reactive cysteine 151 in the chemopreventive agent-sensor Keap1 protein is method-dependent. Chem. Res. Toxicol.2007, 20, 1878-1884.

95. Zhang, D.D.; Hannink, M. Distinct cysteine residues in keap1 are required for keap1-dependent ubiquitination of nrf2 and for stabilization of nrf2 by chemopreventive agents and oxidative stress. Mol. Cell Biol. 2003, 23, 8137-8151. 
96. Chan, K.; Kan, Y.W. Nrf2 is essential for protection against acute pulmonary injury in mice. Proc. Natl. Acad. Sci. USA 1999, 96, 12731-12736.

97. Cho, H.Y.; Jedlicka, A.E.; Reddy, S.P.; Kensler, T.W.; Yamamoto, M.; Zhang, L.Y.; Kleeberger, S.R. Role of NRF2 in protection against hyperoxic lung injury in mice. Am. J. Respir. Cell Mol. Biol. 2002, 26, 175-182.

98. Cho, H.Y.; Jedlicka, A.E.; Reddy, S.P.; Zhang, L.Y.; Kensler, T.W.; Kleeberger, S.R. Linkage analysis of susceptibility to hyperoxia. Nrf2 is a candidate gene. Am. J. Respir. Cell Mol. Biol. 2002, 26, 42-51.

99. Cho, J.M.; Manandhar, S.; Lee, H.R.; Park, H.M.; Kwak, M.K. Role of the Nrf2-antioxidant system in cytotoxicity mediated by anticancer cisplatin: implication to cancer cell resistance. Cancer Lett. 2008, 260, 96-108.

100. Kwak, M.K.; Ramos-Gomez, M.; Wakabayashi, N.; Kensler, T.W. Chemoprevention by 1,2dithiole-3-thiones through induction of NQO1 and other phase 2 enzymes. Methods Enzymol. 2004, 382, 414-423.

101. Osburn, W.O.; Wakabayashi, N.; Misra, V.; Nilles, T.; Biswal, S.; Trush, M.A.; Kensler, T.W. $\mathrm{Nrf2}$ regulates an adaptive response protecting against oxidative damage following diquatmediated formation of superoxide anion. Arch. Biochem. Biophys. 2006, 454, 7-15.

102. Ramos-Gomez, M.; Dolan, P.M.; Itoh, K.; Yamamoto, M.; Kensler, T.W. Interactive effects of nrf2 genotype and oltipraz on benzoa.pyrene-DNA adducts and tumor yield in mice. Carcinogenesis 2003, 24, 461-467.

103. Aoki, Y.; Sato, H.; Nishimura, N.; Takahashi, S.; Itoh, K.; Yamamoto, M. Accelerated DNA adduct formation in the lung of the Nrf2 knockout mouse exposed to diesel exhaust. Toxicol. Appl. Pharmacol. 2001, 173, 154-160.

104. Iida, K.; Itoh, K.; Kumagai, Y.; Oyasu, R.; Hattori, K.; Kawai, K.; Shimazui, T.; Akaza, H.; Yamamoto, M. Nrf2 is essential for the chemopreventive efficacy of oltipraz against urinary bladder carcinogenesis. Cancer Res. 2004, 64, 6424-6431.

105. Jiang, T.; Huang, Z.; Chan, J.Y.; Zhang, D.D. Nrf2 protects against As(III)-induced damage in mouse liver and bladder. Toxicol. Appl. Pharmacol. 2009, 240, 8-14.

106. Thimmulappa, R.K.; Scollick, C.; Traore, K.; Yates, M.; Trush, M.A.; Liby, K.T.; Sporn, M.B.; Yamamoto, M.; Kensler, T.W.; Biswal, S. Nrf2-dependent protection from LPS induced inflammatory response and mortality by CDDO-Imidazolide. Biochem. Biophys. Res. Commun. 2006, 351, 883-889.

107. Zhu, H.; Jia, Z.; Zhang, L.; Yamamoto, M.; Misra, H.P.; Trush, M.A.; Li, Y. Antioxidants and phase 2 enzymes in macrophages: regulation by Nrf2 signaling and protection against oxidative and electrophilic stress. Exp. Biol. Med. (Maywood) 2008, 233, 463-474.

108. Cho, H.Y.; Reddy, S.P.; Yamamoto, M.; Kleeberger, S.R. The transcription factor NRF2 protects against pulmonary fibrosis. FASEB J. 2004, 18, 1258-1260.

109. Shin, D.H.; Park, H.M.; Jung, K.A.; Choi, H.G.; Kim, J.A.; Kim, D.D.; Kim, S.G.; Kang, K.W.; $\mathrm{Ku}$, S.K.; Kensler, T.W.; Kwak, M.K. The NRF2-heme oxygenase-1 system modulates cyclosporin A-induced epithelial-mesenchymal transition and renal fibrosis. Free Radic. Biol. Med. 2010, 48, 1051-1063. 
110. Surh, Y.J.; Kundu, J.K.; Na, H.K. Nrf2 as a master redox switch in turning on the cellular signaling involved in the induction of cytoprotective genes by some chemopreventive phytochemicals. Planta Med. 2008, 74, 1526-1539.

111. Chung, F.L.; Conaway, C.C.; Rao, C.V.; Reddy, B.S. Chemoprevention of colonic aberrant crypt foci in Fischer rats by sulforaphane and phenethyl isothiocyanate. Carcinogenesis 2000, 21, 2287-2291.

112. Clarke, J.D.; Dashwood, R.H.; Ho, E. Multi-targeted prevention of cancer by sulforaphane. Cancer Lett. 2008, 269, 291-304.

113. Fahey, J.W.; Haristoy, X.; Dolan, P.M.; Kensler, T.W.; Scholtus, I.; Stephenson, K.K.; Talalay, P.; Lozniewski, A. Sulforaphane inhibits extracellular, intracellular, and antibiotic-resistant strains of Helicobacter pylori and prevents benzoa.pyrene-induced stomach tumors. Proc. Natl. Acad. Sci. USA 2002, 99, 7610-7615.

114. Juge, N.; Mithen, R.F.; Traka, M. Molecular basis for chemoprevention by sulforaphane: a comprehensive review. Cell Mol Life Sci. 2007, 64, 1105-1127.

115. Zhang, Y.; Kensler, T.W.; Cho, C.G.; Posner, G.H.; Talalay, P. Anticarcinogenic activities of sulforaphane and structurally related synthetic norbornyl isothiocyanates. Proc. Natl. Acad. Sci. USA 1994, 91, 3147-3150.

116. Kensler, T.W.; Egner, P.A.; Dolan, P.M.; Groopman, J.D.; Roebuck, B.D. Mechanism of protection against aflatoxin tumorigenicity in rats fed 5-(2-pyrazinyl)-4-methyl-1,2-dithiol-3thione (oltipraz) and related 1,2-dithiol-3-thiones and 1,2-dithiol-3-ones. Cancer Res. 1987, 47, 4271-4277.

117. Kensler, T.W.; Groopman, J.D.; Eaton, D.L.; Curphey, T.J.; Roebuck, B.D. Potent inhibition of aflatoxin-induced hepatic tumorigenesis by the monofunctional enzyme inducer 1,2-dithiole-3thione. Carcinogenesis 1992, 13, 95-100.

118. Kensler, T.W.; Groopman, J.D.; Sutter, T.R.; Curphey, T.J.; Roebuck, B.D. Development of cancer chemopreventive agents: oltipraz as a paradigm. Chem. Res. Toxicol. 1999, 12, 113-126.

119. Roebuck, B.D.; Curphey, T.J.; Li, Y.; Baumgartner, K.J.; Bodreddigari, S.; Yan, J.; Gange, S.J.; Kensler, T.W.; Sutter, T.R. Evaluation of the cancer chemopreventive potency of dithiolethione analogs of oltipraz. Carcinogenesis 2003, 24, 1919-1928.

120. Aziz, M.H.; Kumar, R.; Ahmad, N. Cancer chemoprevention by resveratrol: in vitro and in vivo studies and the underlying mechanisms (review). Int. J. Oncol. 2003, 23, 17-28.

121. Juan, M.E.; Vinardell, M.P.; Planas, J.M. The daily oral administration of high doses of transresveratrol to rats for 28 days is not harmful. J. Nutr. 2002, 132, 257-260.

122. Surh, Y.J. Cancer chemoprevention with dietary phytochemicals. Nat. Rev. Cancer 2003, 3, 768-780.

123. Athar, M.; Back, J.H.; Tang, X.; Kim, K.H.; Kopelovich, L.; Bickers, D.R.; Kim, A.L. Resveratrol: a review of preclinical studies for human cancer prevention. Toxicol. Appl. Pharmacol. 2007, 224, 274-283.

124. Singh, S.; Khar, A. Biological effects of curcumin and its role in cancer chemoprevention and therapy. Anticancer Agents Med. Chem. 2006, 6, 259-270. 
125. Dhillon, N.; Aggarwal, B.B.; Newman, R.A.; Wolff, R.A.; Kunnumakkara, A.B.; Abbruzzese, J.L.; Ng, C.S.; Badmaev, V.; Kurzrock, R. Phase II trial of curcumin in patients with advanced pancreatic cancer. Clin. Cancer Res. 2008, 14, 4491-4499.

126. Hatcher, H.; Planalp, R.; Cho, J.; Torti, F.M.; Torti, S.V. Curcumin: from ancient medicine to current clinical trials. Cell Mol. Life Sci. 2008, 65, 1631-1652.

127. Nagaoka, T.; Banskota, A.H.; Tezuka, Y.; Saiki, I.; Kadota, S. Selective antiproliferative activity of caffeic acid phenethyl ester analogues on highly liver-metastatic murine colon 26-L5 carcinoma cell line. Bioorg. Med. Chem. 2002, 10, 3351-3359.

128. Zhang, Y.; Talalay, P.; Cho, C.G.; Posner, G.H. A major inducer of anticarcinogenic protective enzymes from broccoli: isolation and elucidation of structure. Proc. Natl. Acad. Sci. USA 1992, 89, 2399-2403.

129. Conaway, C.C.; Wang, C.X.; Pittman, B.; Yang, Y.M.; Schwartz, J.E.; Tian, D.; McIntee, E.J.; Hecht, S.S.; Chung, F.L. Phenethyl isothiocyanate and sulforaphane and their N-acetylcysteine conjugates inhibit malignant progression of lung adenomas induced by tobacco carcinogens in A/J mice. Cancer Res. 2005, 65, 8548-8557.

130. Zhang, Y.; Munday, R. Dithiolethiones for cancer chemoprevention: where do we stand? Mol. Cancer Ther. 2008, 7, 3470-3479.

131. O'Dwyer, P.J.; Szarka, C.E.; Yao, K.S.; Halbherr, T.C.; Pfeiffer, G.R.; Green, F.; Gallo, J.M.; Brennan, J.; Frucht, H.; Goosenberg, E.B.; Hamilton, T.C.; Litwin, S.; Balshem, A.M.; Engstrom, P.F.; Clapper, M.L. Modulation of gene expression in subjects at risk for colorectal cancer by the chemopreventive dithiolethione oltipraz. J. Clin. Invest. 1996, 98, 1210-1217.

132. Wang, J.S.; Shen, X.; He, X.; Zhu, Y.R.; Zhang, B.C.; Wang, J.B.; Qian, G.S.; Kuang, S.Y.; Zarba, A.; Egner, P.A.; Jacobson, L.P.; Munoz, A.; Helzlsouer, K.J.; Groopman, J.D.; Kensler, T.W. Protective alterations in phase 1 and 2 metabolism of aflatoxin B1 by oltipraz in residents of Qidong, People's Republic of China. J. Natl. Cancer Inst. 1999, 91, 347-354.

133. Leiro, J.; Alvarez, E.; Arranz, J.A.; Laguna, R.; Uriarte, E.; Orallo, F. Effects of cis-resveratrol on inflammatory murine macrophages: antioxidant activity and down-regulation of inflammatory genes. J. Leukoc. Biol .2004, 75, 1156-1165.

134. Lopez-Velez, M.; Martinez-Martinez, F.; Del Valle-Ribes, C. The study of phenolic compounds as natural antioxidants in wine. Crit. Rev. Food Sci. Nutr. 2003, 43, 233-244.

135. Miller, N.J.; Rice-Evans, C.A. Antioxidant activity of resveratrol in red wine. Clin. Chem. 1995, 41, 1789.

136. Chen, C.Y.; Jang, J.H.; Li, M.H.; Surh, Y.J. Resveratrol upregulates heme oxygenase-1 expression via activation of NF-E2-related factor 2 in PC12 cells. Biochem. Biophys. Res. Commun. 2005, 331, 993-1000.

137. Kode, A.; Rajendrasozhan, S.; Caito, S.; Yang, S.R.; Megson, I.L.; Rahman, I. Resveratrol induces glutathione synthesis by activation of $\mathrm{Nrf} 2$ and protects against cigarette smokemediated oxidative stress in human lung epithelial cells. Am. J. Physiol. Lung Cell Mol. Physiol. 2008, 294, L478-488.

138. Rubiolo, J.A.; Mithieux, G.; Vega, F.V. Resveratrol protects primary rat hepatocytes against oxidative stress damage: activation of the Nrf2 transcription factor and augmented activities of antioxidant enzymes. Eur. J. Pharmacol. 2008, 591, 66-72. 
139. Ammon, H.P.; Wahl, M.A. Pharmacology of Curcuma longa. Planta Med. 1991, 57, 1-7.

140. Balogun, E.; Hoque, M.; Gong, P.; Killeen, E.; Green, C.J.; Foresti, R.; Alam, J.; Motterlini, R. Curcumin activates the haem oxygenase-1 gene via regulation of Nrf2 and the antioxidantresponsive element. Biochem. J. 2003, 371, 887-895.

141. Garg, R.; Gupta, S.; Maru, G.B. Dietary curcumin modulates transcriptional regulators of phase I and phase II enzymes in benzoa.pyrene-treated mice: mechanism of its anti-initiating action. Carcinogenesis 2008, 29, 1022-1032.

142. Calabro, P.; Yeh, E.T. The pleiotropic effects of statins. Curr Opin Cardiol 2005, 20, 541-546.

143. Shaw, S.M.; Fildes, J.E.; Yonan, N.; Williams, S.G. Pleiotropic effects and cholesterol-lowering therapy. Cardiology 2009, 112, 4-12.

144. D'Amico, G. Statins and renal diseases: from primary prevention to renal replacement therapy. $J$. Am. Soc. Nephrol. 2006, 17, S148-152.

145. Dulak, J.; Jozkowicz, A. Anti-angiogenic and anti-inflammatory effects of statins: relevance to anti-cancer therapy. Curr .Cancer Drug Targets 2005, 5, 579-594.

146. Immenschuh, S.; Baumgart-Vogt, E.; Mueller, S. Heme Oxygenase-1 and Iron in Liver Inflammation: a Complex Alliance. Curr .Drug Targets 2010,

147. Paine, A.; Eiz-Vesper, B.; Blasczyk, R.; Immenschuh, S. Signaling to heme oxygenase-1 and its anti-inflammatory therapeutic potential. Biochem. Pharmacol. 2010,

148. Khor, T.O.; Yu, S.; Kong, A.N. Dietary cancer chemopreventive agents - targeting inflammation and Nrf2 signaling pathway. Planta Med. 2008, 74, 1540-1547.

149. Kwak, M.K.; Wakabayashi, N.; Greenlaw, J.L.; Yamamoto, M.; Kensler, T.W. Antioxidants enhance mammalian proteasome expression through the Keap1-Nrf2 signaling pathway. Mol. Cell Biol. 2003, 23, 8786-8794.

150. Kwak, M.K.; Huang, B.; Chang, H.; Kim, J.A.; Kensler, T.W. Tissue specific increase of the catalytic subunits of the $26 \mathrm{~S}$ proteasome by indirect antioxidant dithiolethione in mice: enhanced activity for degradation of abnormal protein. Life Sci. 2007, 80, 2411-2420.

151. Halliwell, B. Hypothesis: proteasomal dysfunction: a primary event in neurogeneration that leads to nitrative and oxidative stress and subsequent cell death. Ann. $N$ Y Acad. Sci. 2002, 962, 182194.

152. Poppek, D.; Grune, T. Proteasomal defense of oxidative protein modifications. Antioxid. Redox Signal 2006, 8, 173-184.

153. Stefani, M.; Dobson, C.M. Protein aggregation and aggregate toxicity: new insights into protein folding, misfolding diseases and biological evolution. J. Mol. Med. 2003, 27, 27.

154. Kwak, M.K.; Cho, J.M.; Huang, B.; Shin, S.; Kensler, T.W. Role of increased expression of the proteasome in the protective effects of sulforaphane against hydrogen peroxide-mediated cytotoxicity in murine neuroblastoma cells. Free Radic. Biol. Med. 2007, 43, 809-817.

155. Shin, S.; Wakabayashi, N.; Misra, V.; Biswal, S.; Lee, G.H.; Agoston, E.S.; Yamamoto, M.; Kensler, T.W. NRF2 modulates aryl hydrocarbon receptor signaling: influence on adipogenesis. Mol. Cell Biol. 2007, 27, 7188-7197.

156. Shin, S.; Wakabayashi, J.; Yates, M.S.; Wakabayashi, N.; Dolan, P.M.; Aja, S.; Liby, K.T.; Sporn, M.B.; Yamamoto, M.; Kensler, T.W. Role of Nrf2 in prevention of high-fat diet-induced obesity by synthetic triterpenoid CDDO-imidazolide. Eur. J. Pharmacol. 2009, 620, 138-144. 
157. Tanaka, Y.; Aleksunes, L.M.; Yeager, R.L.; Gyamfi, M.A.; Esterly, N.; Guo, G.L.; Klaassen, C.D. NF-E2-related factor 2 inhibits lipid accumulation and oxidative stress in mice fed a highfat diet. J. Pharmacol. Exp .Ther. 2008, 325, 655-664.

158. Beyer, T.A.; Xu, W.; Teupser, D.; auf dem Keller, U.; Bugnon, P.; Hildt, E.; Thiery, J.; Kan, Y.W.; Werner, S. Impaired liver regeneration in Nrf2 knockout mice: role of ROS-mediated insulin/IGF-1 resistance. EMBO J. 2008, 27, 212-223.

159. Beyer, T.A.; Werner, S. The cytoprotective Nrf2 transcription factor controls insulin receptor signaling in the regenerating liver. Cell Cycle 2008, 7, 874-878.

160. Wakabayashi, N.; Shin, S.; Slocum, S.L.; Agoston, E.S.; Wakabayashi, J.; Kwak, M.K.; Misra, V.; Biswal, S.; Yamamoto, M.; Kensler, T.W. Regulation of notch1 signaling by nrf2: implications for tissue regeneration. Sci. Signal 2010, 3, ra52.

161. Kang, K.W.; Choi, S.H.; Ha, J.R.; Kim, C.W.; Kim, S.G. Inhibition of dimethylnitrosamineinduced liver fibrosis by 5-(2-pyrazinyl)-4-methyl-1,2-dithiol-3-thione. (oltipraz) in rats: suppression of transforming growth factor-betal and tumor necrosis factor-alpha expression. Chem. Biol. Interact 2002, 139, 61-77.

162. Kang, K.W.; Kim, Y.G.; Cho, M.K.; Bae, S.K.; Kim, C.W.; Lee, M.G.; Kim, S.G. Oltipraz regenerates cirrhotic liver through CCAAT/enhancer binding protein-mediated stellate cell inactivation. FASEB J. 2002, 16, 1988-1990.

163. Talalay, P.; De Long, M.J.; Prochaska, H.J. Identification of a common chemical signal regulating the induction of enzymes that protect against chemical carcinogenesis. Proc. Natl. Acad. Sci. USA 1988, 85, 8261-8265.

164. Kobayashi, M.; Li, L.; Iwamoto, N.; Nakajima-Takagi, Y.; Kaneko, H.; Nakayama, Y.; Eguchi, M.; Wada, Y.; Kumagai, Y.; Yamamoto, M. The antioxidant defense system Keap1-Nrf2 comprises a multiple sensing mechanism for responding to a wide range of chemical compounds. Mol. Cell Biol. 2009, 29, 493-502.

165. Holland, R.; Hawkins, A.E.; Eggler, A.L.; Mesecar, A.D.; Fabris, D.; Fishbein, J.C. Prospective type 1 and type 2 disulfides of Keap1 protein. Chem. Res. Toxicol. 2008, 21, 2051-2060.

(C) 2010 by the authors; licensee MDPI, Basel, Switzerland. This article is an open access article distributed under the terms and conditions of the Creative Commons Attribution license (http://creativecommons.org/licenses/by/3.0/). 